\title{
Radiation synthesis and characterization of Pectin/acrylamide (PEC/AM) and Pectin/Diethylaminomethylmethacrylate (PEC/DEAMA) hydrogels as Drug

\author{
delivery systems
}

Faten. I. Abou El Fadl., Nabila. A. Maziad

National Center for Radiation Research and Technology, P.O. Box 29, Nasr City, Cairo, Egypt

\begin{abstract}
Hydrogels of natural and synthetic copolymers were gained a great attention in recent years. In this work, we aimed to prepare different copolymer hydrogels of Pectin/Acrylamide (PEC/PAM) and Pectin/Diethylaminoethylmethacrylate (PEC/DEAMA) using gamma irradiation. These hydrogels were studied and characterized by different techniques as, FTIR,TGA and SEM. The hydrogels were also, characterized in terms of gel content, and swelling at different $\mathrm{pH}$ and different temperature. The results showed that the gel fraction of PEC/PAM hydrogels decreases greatly with decreasing the contents of PEC and also the gel fraction increases with increasing irradiation dose up to $2.5 \mathrm{Mr}$ then decreases with further increase of radiation dose. While for the PEC/DEAMA hydrogels, it is noticed that as the DEAMA content increases the gel content decrease. Water uptake percent was studied through the effect of temperature, it was found that the swelling of all the hydrogels changes within the temperature range $30-80{ }^{\circ} \mathrm{C}$, it was found that water uptake percent increases as temperature increase for the system PEC/PAM and decreased for the system PEC/DEAMA. Also, waterup take studid as a function of $\mathrm{pH}$ within the $\mathrm{pH}$ range $2-8$. Results prove that water uptake percent increases as $\mathrm{pH}$ increas for both systems. However, the swelling of PEC/PAM hydrogels was greater than the hydrogel based on PEC/DEAMA. The swelling kinetic studies showed that the swelling of all the hydrogels affected by the $\mathrm{pH}$ of the medium and the temperature and also, the highest percentage of swelling rate occurred at the first stagess of swelling time. The Pectin hydrogels was evaluated for the possible use in drug delivery systems. In this respect, the release properties of tetracycline HCL, as a model drug, was investigated. It was found that the percentage release from the hydrogels increase with time, and also the percentage release was examined at different $\mathrm{pH}$ values, where the highest release percentage occurred at $\mathrm{pH} 8$ for both copolymer systems.
\end{abstract}

Keywords

Pectin, poly acrylamide, DEAMA, Drug Release, Tetracycline HCL

\section{Introduction}

Radiation processing offers a clean and additive-free method for preparation of valueadded novel materials based on renew- able, non-toxic and biodegradable natural polymers, and natural polymer waste. The results of research work showed that depending on the irradiation conditions, natural polysaccharides (alginate, chitin/chitosan, carrageeneans, carboxylmethylcellu- lose, etc.) could be either degraded or crosslinked by radiation. This paved the way for development of many successful applications; some of them commercialized for use in agriculture, health care, and environmental protection. Crosslinked natural polymers can be used as 
hydrogel especially with highly gelable synthetic polymers. In many different medical and pharmaceutical applications especially as drug release systems. hydrogels based of natural polymers and synthetic polymers have gained a great applicability as drug delivery systems. Generally all polymeric gels are either natural (e.g. cross-linked guar gum and collagens) or synthetic ones. On the other hand, hydrogels can be divided into two groups depending on cross-linking nature. If the cross-linking reaction involves formation of covalent bonds between polymer chains, hydrogels are termed as permanent ones, for example various hydrogels based on the acrylic monomers. If hydrogels are formed due to physical interactions (hydrogen bonding, ionic interaction, van der Waals interactions, and molecular entanglement) among the polymeric chains, the hydrogels are termed as physical hydrogels (e.g. gelatine and agar-agar hydrogels) (Hoffman AS, et al 2002). Hydrogels can also be classified as conventional and stimulus responsive ones. Conventional hydrogels are the crosslinked polymer chains which absorb water from aqueous medium without any change in the equilibrium swelling with the change in $\mathrm{pH}$, temperature, electric field or other external stimuli of the environment; while the stimulus responsive (smart or intelligent) hydrogels are polymeric networks which rapidly change their equilibrium swelling with the change of the environment. Many physical and chemical stimuli can be applied to induce different responses of smart hydrogel systems. Physical stimuli include temperature, pressure, light, electric, magnetic, and sound fields. Chemical or biochemical stimuli comprise $\mathrm{pH}$, ionic strength, ions or specific molecular recognition events. Classification of environment stimulus responsive hydrogels is based on external stimuli type. According to their nature smart hydrogels can be classified as thermo-sensitive, $\mathrm{pH}$ sensitive, Thermo-sensitive hydrogels are best studied polymer systems (Kost J, and Langer R, 2001). Polyacrylamide as an example of synthetic polymers used widely in this field due to its high gelability. Chemically, pectin is poly $\alpha 1-4$-galacturonic acids (Fig.1a), with varying degree of methylation of carboxylic acid residues and/or amidated polygalacturonic acids (Fig. 1b) (Mishra, Banthia, \& Majeed, 2012; White, Katona, \& Zodda, 1999). Pectin based biomaterials are used for tissue engineering (Coimbra et al., 2011), wound dressing (Munarin, Tanzi, \& Petrini, 2012), gene transfer (Katav et al., 2008), drug delivery (Smistad, Bøyum, Alund, Samuelsen, \& Hiorth, 2012) and cancer targeting (Dutta \& Sahu, 2012). However, due to poor mechanical properties, it is mostly blended with other polymers. Tetracycline is a yellow, odorless, crystalline powder. Tetracycline is stable in air but exposure to strong sunlight causes it to darken. Its potency is affected in solutions of $\mathrm{pH}$ below 2 and is rapidly destroyed by alkali hydroxide solutions. Tetracycline is very slightly soluble in water, freely soluble in dilute acid and in alkali hydroxide solutions, sparingly soluble in alcohol, and practically insoluble in chloroform and in ether. The chemical name for tetracycline hydrochloride is 4(Dimethylamino)-1,4,4a,5,5a,6,11,12a-octahydro-3,6,10,12,-12a-pentahydroxy-6-

methyl-1,11-dioxo-2-naphthacenecar-boxamide monohydrochloride. Tetracycline Hydrochloride) is used to treat many different bacterial infections, such as urinary tract infections, acne, gonorrhea, chlamydia, and others. In this study we aimed to prepare different hydrogels, by using gamma radiation, based on pectin. These hydrogels were characterized and studied for using as drug delivery system for tetracycline HCL as a drug model.

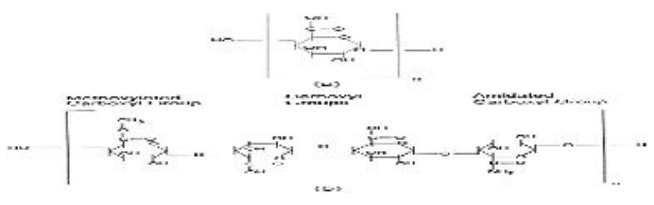


Fig. 1. Chemical structure of polygalacturonic acid (a) and representative chemical structure of pectin showing typical repeating groups $(b)$.

\section{Experimental}

\subsection{Materials}

Pectin and acrylamide were purchased from Sigma Aldrich. Chlortetracycline HCL and DEAMA were purchased from Sigma Aldrich. Sodium hydroxide $(0.5 \mathrm{M})$ (99.99\%), HCL 1M and buffer salts were purchased from Al Gomhoria Co. Egypt). Double-distilled water was used for the preparation of all solutions in this study. All reagents and Metal salts were in analytical grade and used without any further purification.

\subsection{Preparation of hydrogel}

Firstly, different compositions (50/50, 60/40, and 80/20) of Pectin with Acrylamid and $(50 / 50$ and 60/40) of PEC with DEAMA were prepared from 5\% (wt/v) concentration of each polymer. It is important to note here that the DEAMA and PEC are not completely miscible at the whole range of compositions and the most miscible compositions prepared are 50/50 and 60/40 (DEAMA/PEC) and chosen for this study, After that, the mixtures were mixed by magnetic stirrer for $30 \mathrm{~min}$ to form a homogenous polymer solutions. Finally, the solution was filled into test tubes (inner diameter $10 \mathrm{~mm}$ ) and subjected to gamma-irradiation at different doses (from 2 to 4 $\mathrm{Mr}$ for PEC/PAM and at $2 \mathrm{Mr}$ for PEC/DEAMA) at ambient temperature using a 60 Co facility. The optimal preparation conditions, such as the compositions of Pectin, acrylamide and DEAMA, were determined later in this work. The transparent hydrogels obtained were removed, and washed with double distilled water.

\subsubsection{Preparation of Drug Loaded hydrogels}

Polymer-drug conjugate was prepared by dissolved different weights of drug (Chlortetracycline HCL as model drugs) $(0.2,0.3,0.35,0.4$ and $0.5 \mathrm{mg}$ ) each in distilled water to prepare $(0.2,0.3,0.35,0.4$ and $0.5 \mathrm{mg} / \mathrm{ml})$ drug concentrations. The dry polymer blends with known weight $(.1 \mathrm{gm})$, were soaked into the drug solution at room temperature until the complete adsorption for $72 \mathrm{hrs}$. Then the amount of drug adsorbed onto polymer hydrogels at different compositions was determined by using UV-vis spectrophotometer at identical drug absorbance wavelength.

\subsection{Swelling studies}

The dried PEC different hydrogels at different compositions were equilibrated in distilled water at different temperatures $(40,50,60$, and $70 \circ \mathrm{C})$ and buffer solutions at different $\mathrm{pH}$ values ( $2,4,6$, and 8 ) until constant weight . The equilibrium swelling capacity or swelling ratio (Q) of PEC/PAM and PEC/DEAMA Hydrogels were calculated by the following the equation:

$\mathbf{Q}=\left(\mathbf{m}_{\mathbf{t}}-\mathbf{m}_{\mathbf{0}} / \mathbf{m}_{\mathbf{0}}\right) \times \mathbf{x 1 0 0}$

where $m_{t}$ is the weight of water in the swollen gel at equilibrium and $m_{0}$ is the dry weight of the dried gel.

\subsubsection{Gel fraction}

hydrogel samples were immersed in deionized water for $4 \mathrm{~h}$ under heating to remove the sol part. After that, the samples were dried at $60{ }^{\circ} \mathrm{C}$ in vacuum. The gel fraction was calculated using Eq.,

Gel Fraction $=\left(G_{d} / G_{i}\right) \times 100$ 
where $G_{i}$ is the initial mass of the sample and $G_{d}$ is the mass of dried gel after extraction.

\subsection{Analyses and Measurements}

\subsubsection{IR Spectroscopic Analysis}

A FTIR spectrometer model Mattson 100, made by Unicam, was used over the range $500-4000 \mathrm{~cm}^{-1}$. For quantitative analysis, the resolution was set at $16 \mathrm{~cm}^{-1}$.

\subsubsection{Ultraviolet (UV) Measurements}

A UV/VIS spectrometer model UV2 series made by Unicam was used at a wavelength of 190-900 nm.

\subsubsection{Thermogravimetric Analysis (TGA)}

The TGA studies were carried out on a Shimadzu 30 (TGA-30) at a heating rate of $10^{\circ 0} \mathrm{C} / \mathrm{min}$. in air over a temperature range from room temperature to $500^{\circ} \mathrm{C}$. The primary TGA thermograms were used to determine the different kinetic parameters such as activation energy and order of thermal decomposition reaction.

\subsubsection{Scanning electron microscopy (SEM)}

The surface morphology of different hydrogel compositions Pectin/PAM and Pectin DEAMA samples were taken with a JSM-5400 instrument by JEOL-Japan. A sputter coater was used to pre-coat conductive gold onto the fracture surface before observing the microstructure at $10 \mathrm{kV}$.

\subsubsection{Drug Release Measurements}

Release experiments were performed by placing the different pectin hydrogels loaded with drug into buffer solutions of $\mathrm{pH} 2,4$ and 8. At first the loaded hydrogels were put in $20 \mathrm{ml}$ of solution. Then the amount of drug released from pectin hydrogels at different compositions was determined by using UV-vis spectrophotometer at identical drug absorbance wavelength. Samples of PEC/PAM and PEC/DEAMA were allowed to swell in buffer solution of $\mathrm{pH} 2$ to 8 . At first the loaded pectin hydrogels were put in $10 \mathrm{ml}$ of solution. Then the permeated amount of Drug was carried out using Perkin Elmer, Lmbda1 UV-Vis spectrophotometer in the range $190-900 \mathrm{~nm}$.

\section{Results and discussion}

\subsection{Gel Fraction of PEC/PAM and PEC/DEAMA}

To study the amount of gel content that formed in the different compositions of PAM/PEC and DEAMA/PEC hydrogels that exposed to different gamma radiation doses the following formula is used, and the effect of radiation dose on the gel fraction is illustrated in Fig.1. that shown below:

Gel Fra ction $=\left(G_{\mathbf{i}} / \mathbf{G}_{\mathbf{d}}\right) \mathbf{X 1 0 0}$

It is noticed from the figure for the PAM/PEC system, that as the PAM content increase the gel fraction increase where the highest gel content occurred at the composition 50/50 (PAM/PEC). By examining the effect of radiation on the gel content, it is noticed that as the irradiation dose increase the gel content increase up to $2.5 \mathrm{Mr}$ then starts to decrease again due to degradation of pectin. Also, studying the effect of polymer content and irradiation dose on the gel content of DEAMA/PEC is 
illustrated in Table1 below where, as the irradiation dose increases the gel content of PEC/DEAMA decreases due to the incrrease in the crossslinking density of the prepared hydrogels.

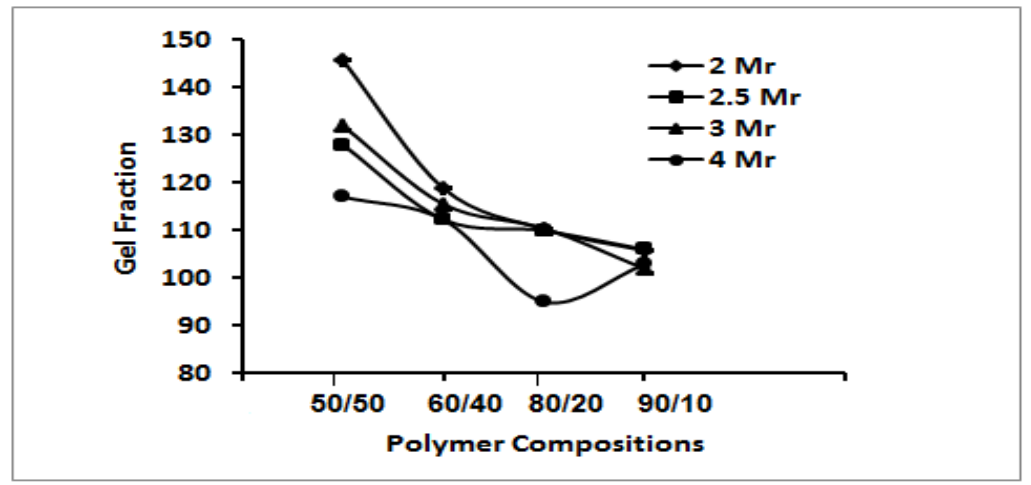

Fig.2. gel fraction of different PEC/PAM compositions at different irradiation doses

Table.1. Gel fraction content of PEC/DEAMA at different doses

\begin{tabular}{|c|c|c|c|}
\hline \multirow{2}{*}{$\begin{array}{c}\text { PEC/DEAMA } \\
\text { hydrogels }\end{array}$} & $\mathbf{3}$ Gr & $\mathbf{2 . 5} \mathbf{~ M r}$ & $\mathbf{4 ~ M r}$ \\
\cline { 2 - 4 } & 107.6628 & 103.69 & 101.0791 \\
\hline 50/50 (DEAMA/PEC) & 105.5807 & 104.4776 & 100.5747 \\
\hline 60/40( DEAMA/PEC) & & & \\
\hline
\end{tabular}

\subsection{Equilibrium swelling}

A fundamental relationship exists between the swelling of a polymer hydrogel in a solvent and the nature of the polymers contents in the hydrogels. The percentage swelling $(\mathrm{S} \%)$ of the prepared hydrogels based on Pectin in water was calculated from the following relation

$\mathbf{S \%}=\left(\left(\mathbf{m}_{\mathbf{t}}-\mathbf{m}_{0}\right) / \mathbf{m}_{0}\right) \times \mathbf{1 0 0}$

Where $\mathrm{m}_{\mathrm{t}}$ is the weight of the swollen gel at time $t$ and $\mathrm{m}_{0}$ is the weight of dry gel at time 0 . The water content of initially dry hydrogels of (50/50) PEC/PAM and 50/50 PEC/DEAMA) were followed over a period of time, gravimetrically. Also, the effect of $\mathrm{pH}$, on the swelling percent at different radiation doses were studied. Swelling isotherm of the different hydrogels of Pectin at the composition (50/50) were constructed and representative swelling curves are shown in the figures below. Figures 2-5 show that the swelling increases with increasing time up to a certain level, then levels off. Also, from studying the figures below it is noticed that as the irradiation dose increase the swelling ratio of both different hydorgels decreases, this attributed to increase in the crosslinking degree of hydrogels with increasing irradiation dose. Studying the effect of $\mathrm{pH}$ value of the solution on the swelling ratios of both hydrogels of Pectin, the results showed, for PEC/PAM system, that the highest degree of swelling occurred at $\mathrm{pH} 8$ and a dose of $2 \mathrm{Mr}$. while for the PEC/DEAMA system the highest degree of swelling occurred at $\mathrm{pH} 2$ and 2.5 Mr. Figure (6) below confirms these results. 


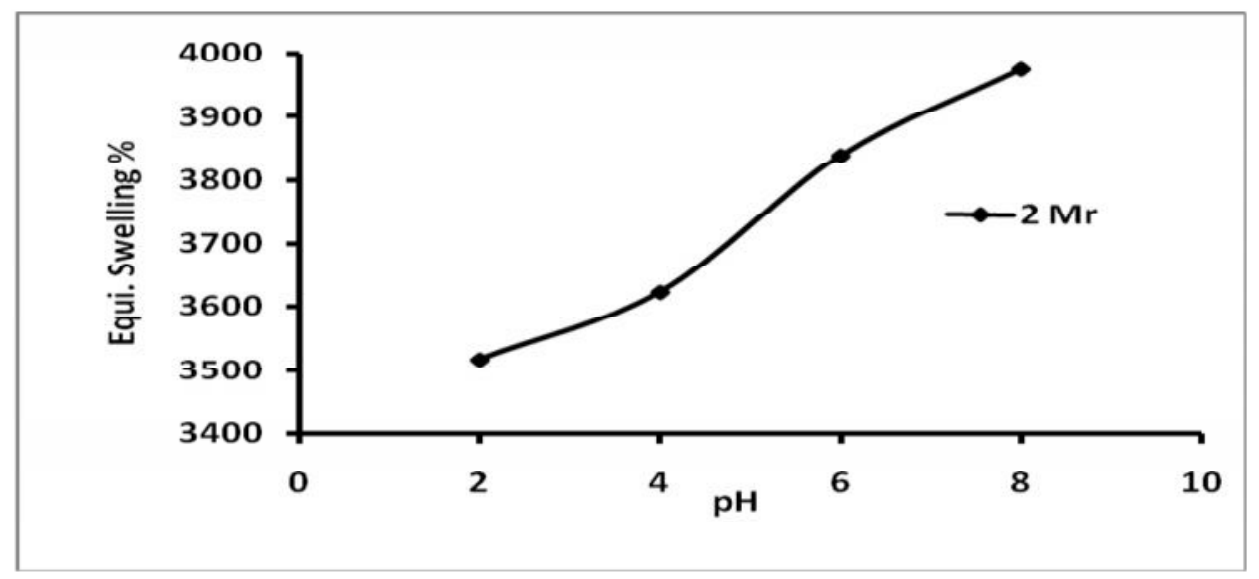

Fig.3. Effect of pH value on the equilibrium swelling of (50/50) PEC/PAM at 2 Mr

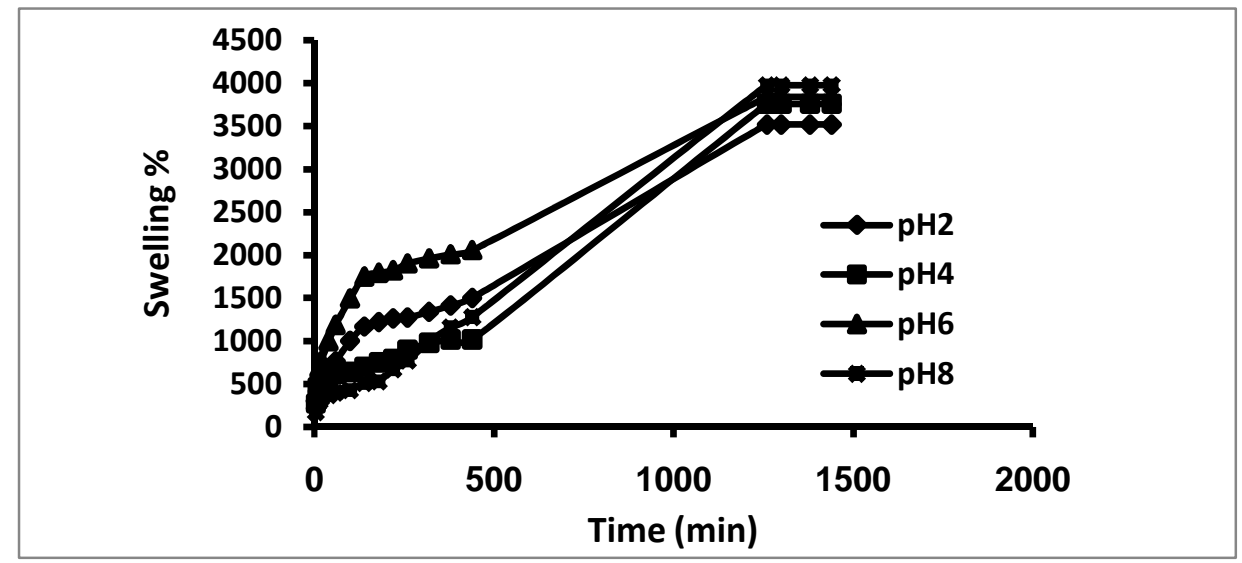

Fig.4. Swelling isotherms of (50/50) PEC/PAM hydrogels at different $\mathrm{pH}$ and at $2 \mathrm{Mr}$

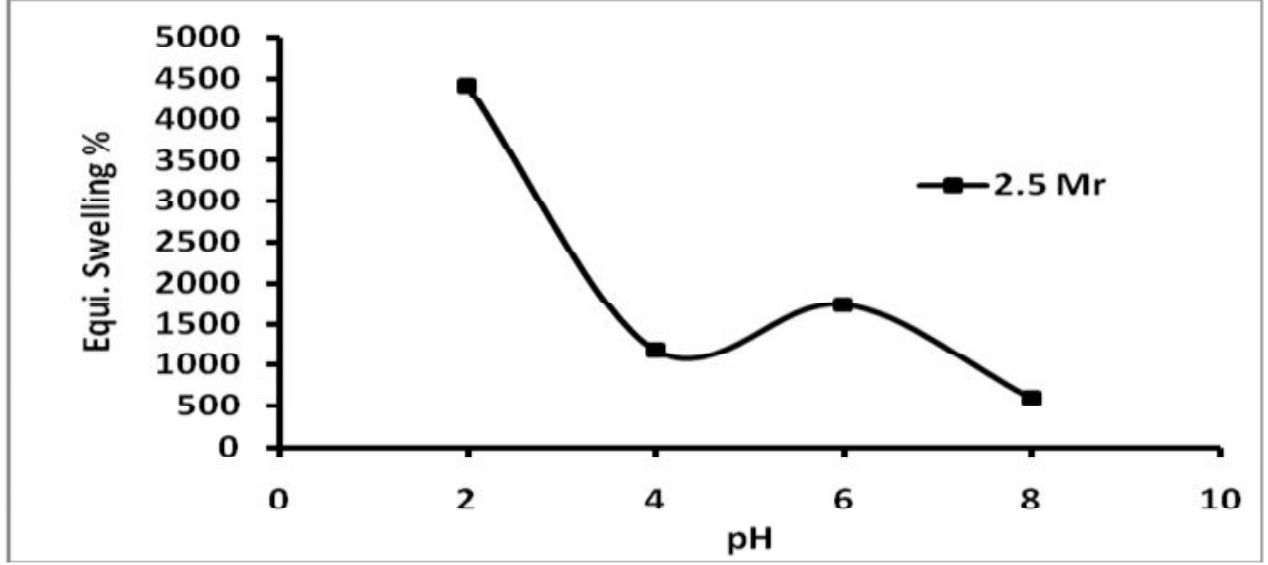

Fig.5. Effect of pH value on the equilibrium swelling of (50/50) PEC/DEAMA at 2.5 Mr 


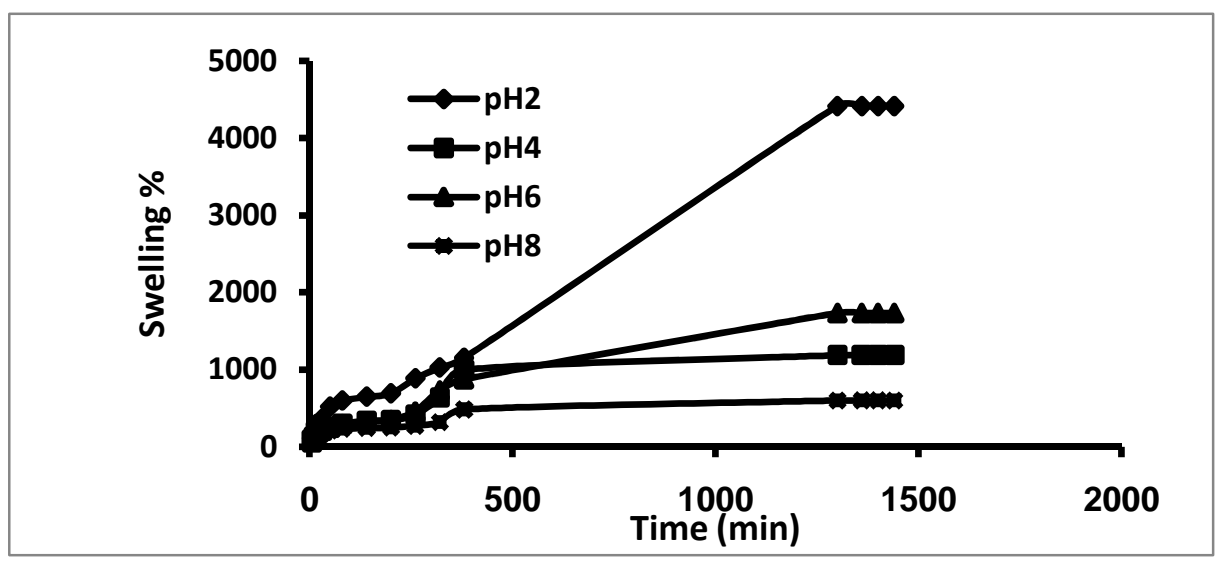

Fig.6. Swelling isotherms of (50/50) PEC/DEAMA hydrogels at different $\mathrm{pH}$ and at $2.5 \mathrm{Mr}$

\subsubsection{Effect of Temperature on swelling ratio}

Figure 6 below shows the effect of temperature on the swelling affinity of (50/50) PEC/PAM and PEC/DEAMA hydrogels that prepared by the effect of radiation. It is noticed that for PEC/PAM hydrogel the swelling affinity increases with increasing temperature up to $80{ }^{0} \mathrm{C}$ while on the other hand the swelling affinity of PEC/DEAMA hydrogel decreases dramatically with increasing temperature up to 80 ${ }^{0} \mathrm{C}$. As a comparison between both PEC hydrogels it is obvious that the swelling affinity of PEC/PAM hydrogels is much more higher than that for PEC/DEAMA.

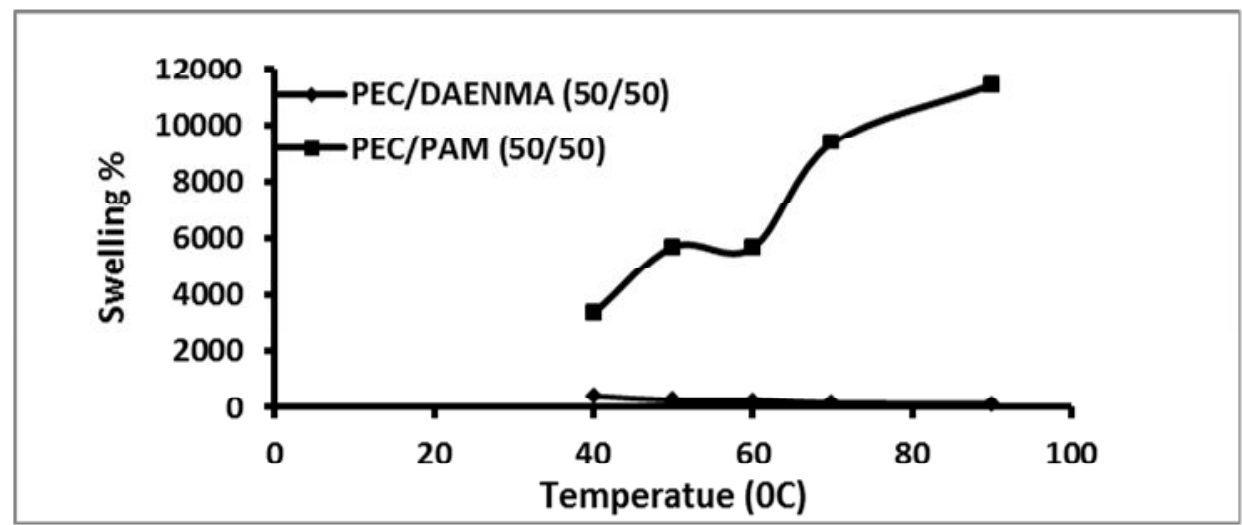

Fig.7. Effect of temperature on the swelling ratio of (50/50) PEC/PAM and PEC/DEAMA

\subsubsection{Swelling Kinetics}

hydrogels

Several kinetics models are used to test the experimental data that is examined the controlling mechanism of the swelling processes of the different Pectin based hydrogels at the optimum composition of (50/50) (S. Kundakci et al (2008). The large number of chemical groups on the polymer chains (e.g. $\mathrm{OH}, \mathrm{NH} 2, \mathrm{C}=\mathrm{O}$, and $\mathrm{COOH}$ ) imply that there are many types of interactions between polymers and solvent. It is probable that any kinetics is likely to be global. A simple kinetic analysis is a second order equation in the form of the following relation:

$\mathbf{d}_{\mathrm{s}} / \mathbf{s}_{\mathrm{t}}=\mathbf{k}_{\mathbf{2}, \mathrm{s}}(\mathrm{S}-\mathrm{St})^{\mathbf{2}}$

where $\mathrm{k}_{2, \mathrm{~s}}$ is the rate constant of swelling and $\mathrm{S}$ is denotes the degree of swelling at equilibrium. After definite integration by applying the initial conditions $S=0$ at $t=0$ and $\mathrm{S}=\mathrm{S}_{\mathrm{t}}$ at $\mathrm{t}=\mathrm{t}$ equation 3 becomes

$\mathbf{t} / \mathbf{S}=\boldsymbol{A}+\mathbf{B t}$

where $A$ is reciprocal of initial swelling rate $\mathrm{r}_{0}$ or $1 / \mathrm{K}_{2, \mathrm{~s}}$ and $\mathrm{B}$ is inverse of the degree of swelling at equilibrium. To test the kinetics model for different compositions of $\mathrm{PAM} / \mathrm{PEC}$ irradiated to $2.5 \mathrm{Mr}$, $\mathrm{t} / \mathrm{S}$ vs. $\mathrm{t}$ graphs are plotted and representative graphs 
are illustrated in Figs. 9 and 10. As it can be seen from the figures kinetics model is in agreement with swelling experiments, since $\left(\mathrm{S}_{\mathrm{eq}} \%\right)$ is changed with PAM and PEC content in the hydrogels. Again, the initial swelling rate is changed with PAM content. This may be important to note that extent of PAM and PEC determines the swelling rate by increasing hydrophilicity.

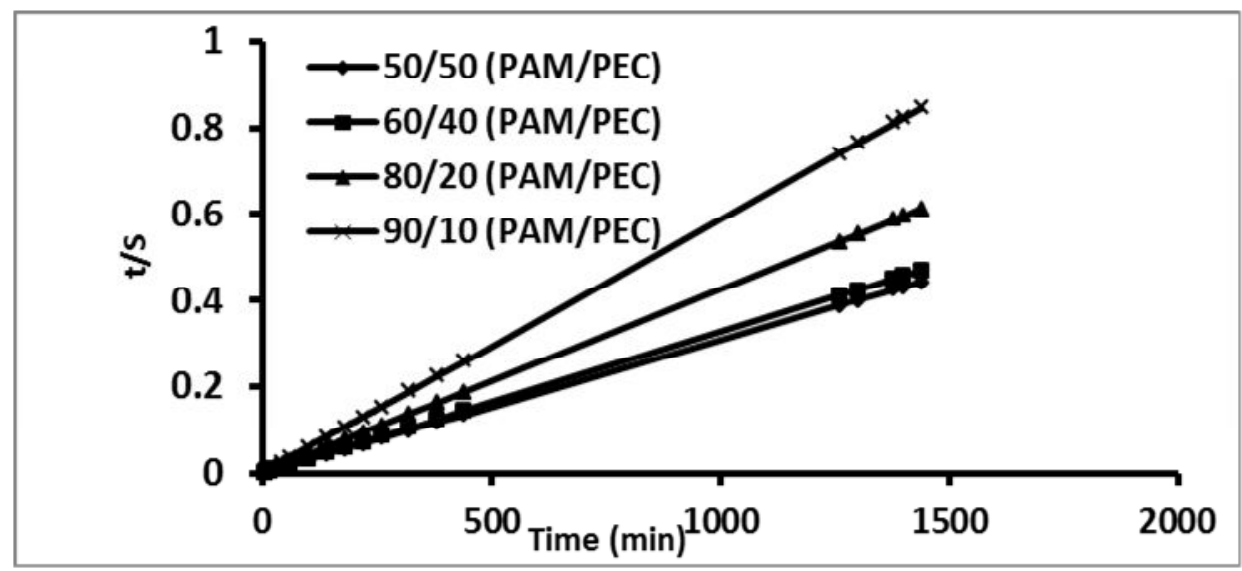

Fig.8. Swelling rate curves of PAM/PEC hydrogels in water

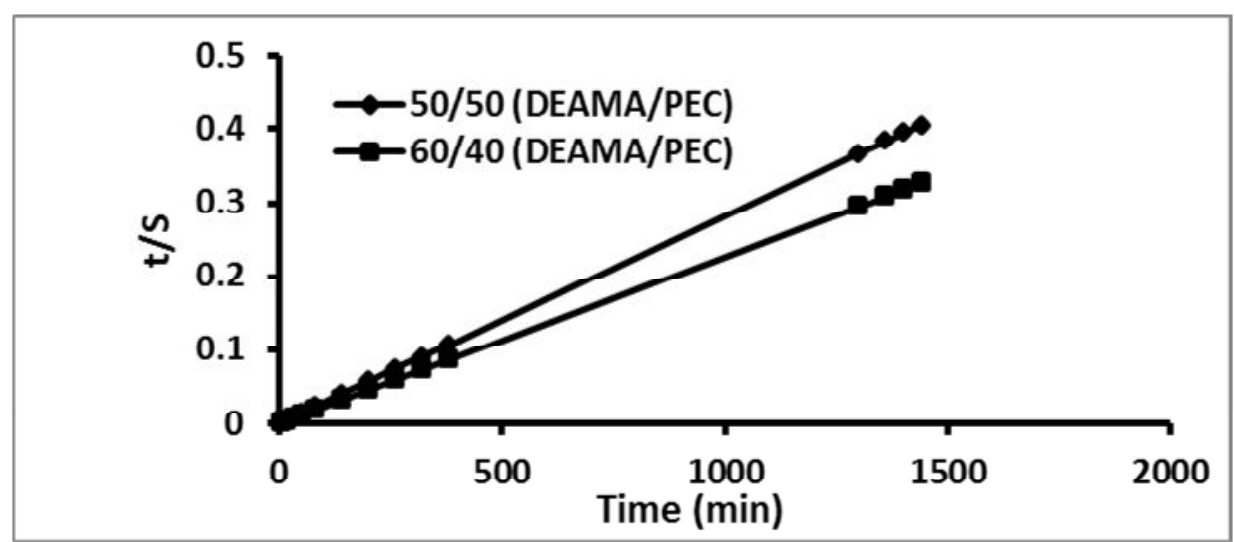

Fig.9. Swelling rate curves of DEAMA/PEC hydrogels in water

\subsection{Thermogravemetric analysis}

The thermograms of the (CS/PAMGA/PAAc) hydrogels and its hydrogel magnetic nanocomposites are shown in Fig.5. all the hydrogels at different compositions have shown three thermal stages of weght loss. The first thermal stage of weght loss occurred at $200-270{ }^{\circ} \mathrm{C}$ and this is attributed to the loss of moisture. The second stage is considered to be due to the degradation of the polymer chains. The third thermal stage which occurred from 450 to $600{ }^{\circ} \mathrm{C}$ may attributed to further degradation of the polymer chains back bone. From these observations it is obveous that the PEC/PAM hydrogel undergo nearly complete degradation at $600{ }^{\circ} \mathrm{C}$. In the case of PEC/DEAMA hydrogels, it is noticed that there 


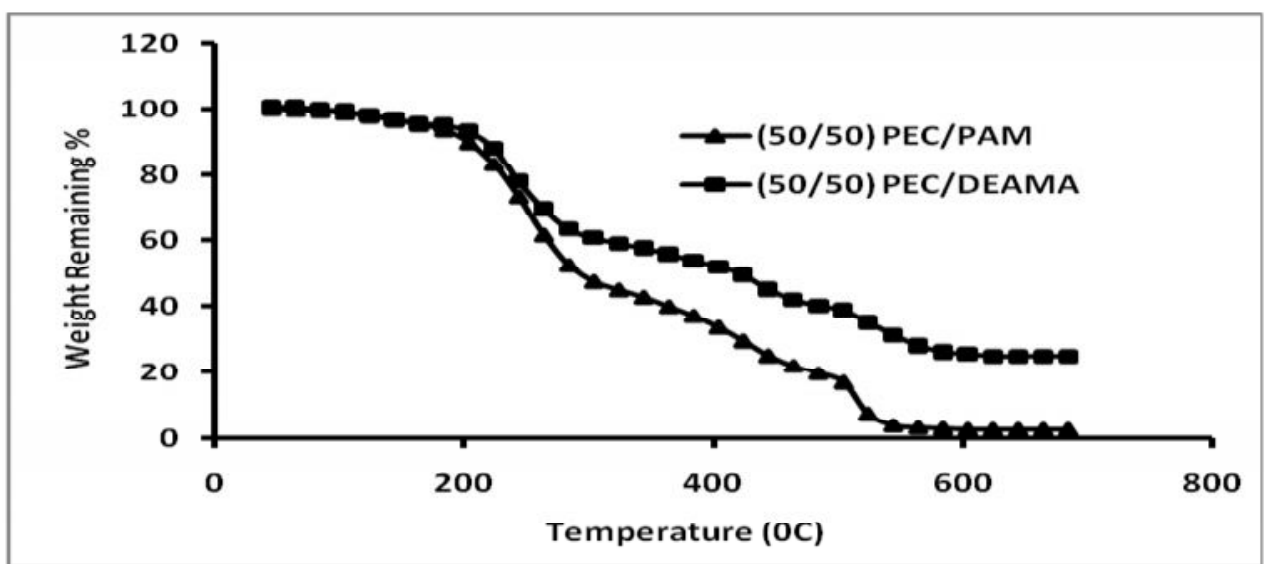

Drug Release

Fig.10. Initial TGA thermograms of (50/50) PEC/PAM and PEC/DEAMA hydrogels

To study the release profiles for test PEC/PAM and PEC/DEAMA hydrogels, dried test samples were immersed in solutions of different $\mathrm{pH}$ values $(2,4$ and 8$)$ to examine the effect of $\mathrm{pH}$ on the release of tetracycline HCL that used as model drug in this study. Fig.9-10 below shows the release profile of entrapped tetracycline under the same varying $\mathrm{pH}$ conditions. The release properties of tetracycline HCL illustrated in Figs. 9-10 are also closely associated with the swelling and degradation behavior of the hydrogels (Figs. 3 - 6). The release of tetracycline as it is noticed from the (50/50) PEC/PAM and PEC/DEAMA hydrogels increases with increasing the initial concentration of drug from $(0.2$ to $0.5 \mathrm{mg} / \mathrm{ml})$. The effect of $\mathrm{pH}$ on the drug release varied as the initial concentration of drug increases from 0.2 to 0.5 as shown in figure( 9) below. It is noticed in the figures below that as the concentration increases the amount released of tetracycline increases with increasing $\mathrm{pH}$ value to 8 where the most released amount achieved at pH8. It is also, noticed that the amount released of drug starts to increase with increasing the initial concentration of drug up to 0.4 $\mathrm{mg} / \mathrm{ml}$ then starts to decrease with increasing the initial concentration of drug.

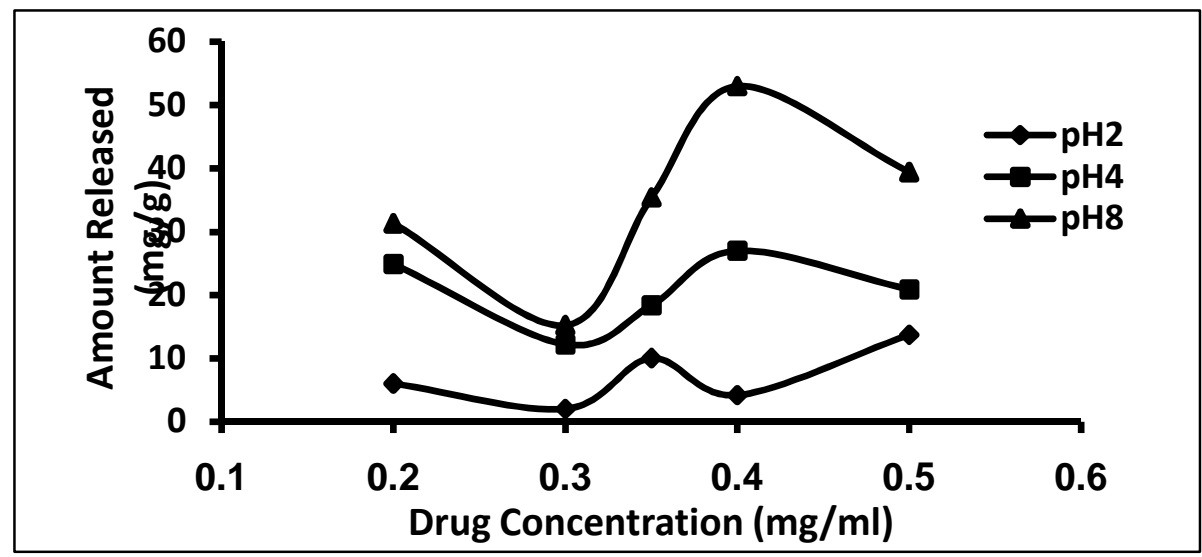

Fig.11. Effect of drug concentration on the amount released at different $\mathrm{pH}$ values 


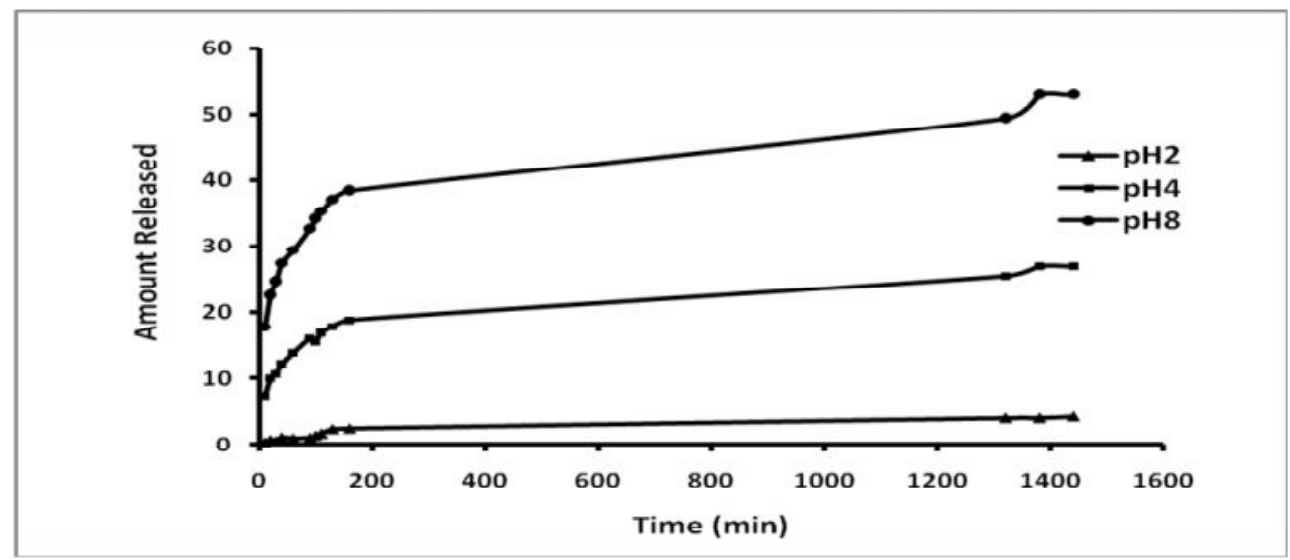

Fig.12. drug release profile for (50/50) PAM/PEC hydrogel at different $\mathrm{pH}$ values and initial Conc. $0.4 \mathrm{mg} / \mathrm{ml}$

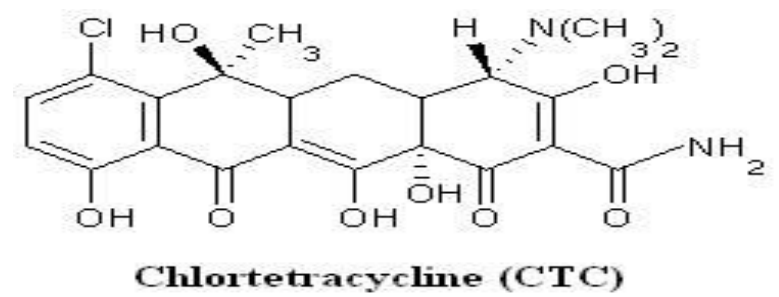

On the other hand, by studying the tetracycline release profiles for the system composed of PEC/DEAMA hydrogels at different initial concentrations of drug it is clearly noticed that the amount released of drug increases by increasing its initial concentration and also the amount releases with time is very small in comparison with the amount released of tetracycline from PEC/PAM hydrogel system. Studying the effect of $\mathrm{pH}$ value of the solution it is observed, on the contrary to the PEC/PAM system, that the highest amount released of drug is achieved at $\mathrm{pH} 2$ at the whole range of initial concentration. By comparison the release profiles of both PEC systems it is worthy to mention that the amount released from PEC/PAM (50/50) hydrogels at different $\mathrm{pH}$ values is higher than that for the PEC/DEAMA (50/50) hydrogels, this can be attributed to that the trapping efficiency of PEC/DEAMA hydrogels for tetracycline HCL is higher than that for PEC/PAM ones.

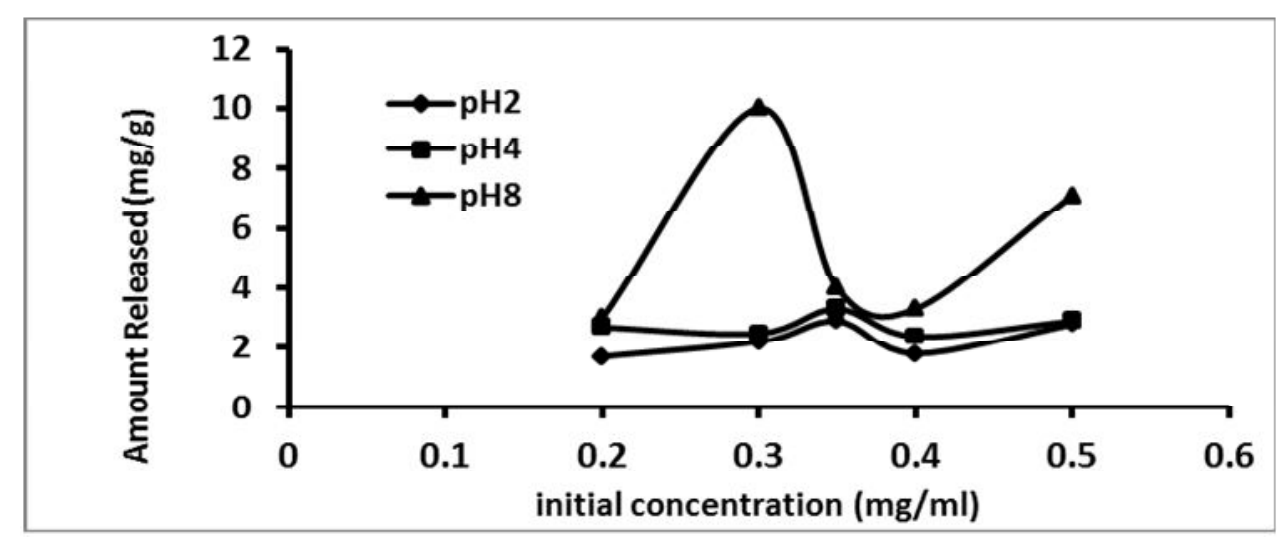

Fig.13. Effect of drug initial concentration on the amount released 


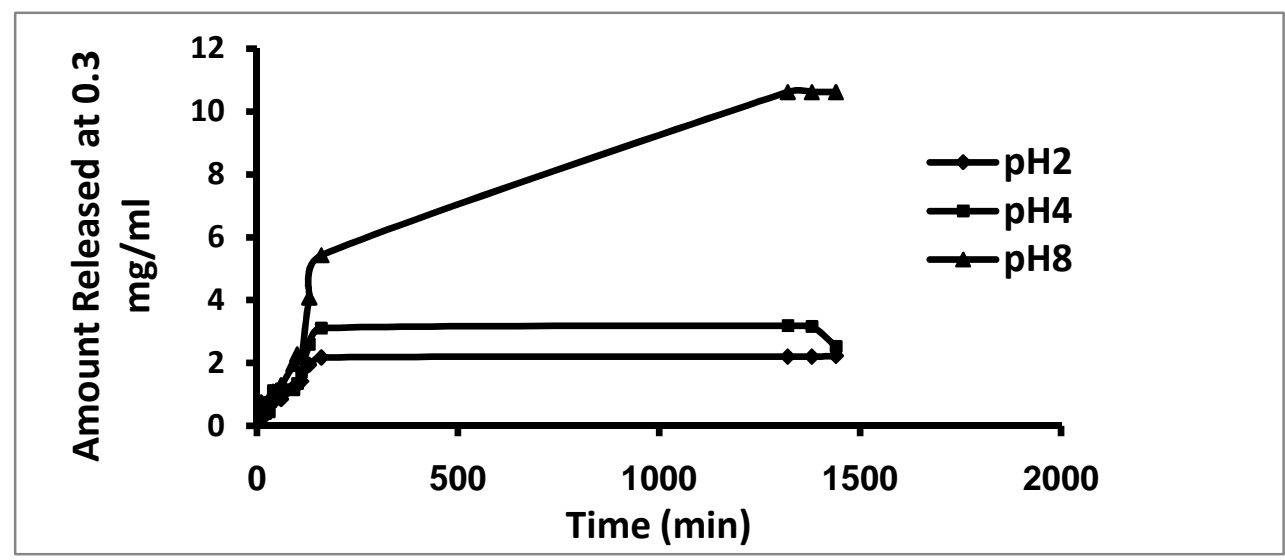

\section{References}

Fig.14. release profile of (50/50) PEC/DEAMA hydrogels at different $\mathrm{pH}$ values

Coimbra, P., Ferreira, P., de Sousa, H. C., Batista, P., Rodrigues, M. A., Correia, I. J., et al. (2011). Preparation and chemical and biological characterization of a pectin/chitosan polyelectrolyte complex scaffold for possible bone tissue engineering applications. International Journal of Biological Macromolecules, 48(1), 112-118. Dutta, R. K., \& Sahu, S. (2012). Development of oxaliplatin encapsulated in magnetic nanocarriers of pectin as a potential targeted drug delivery for cancer therapy.

Results in Pharma Sciences, 2, 38-45.

Hoffman AS. Adv Drug Deliv Rev 2002;54:3.

Kost J, Langer R. Adv Drug Deliv Rev 2001;46:125.

Mishra, R. K., Banthia, A. K., \& Majeed, A. B. A. (2012). Pectin based formulations for biomedical applications: a review. Asian Journal of Pharmaceutical and Clinical Research, 5(4), $1 \mathrm{e} 7$.

Katav, T., Liu, L., Traitel, T., Goldbart, R., Wolfson, M., \& Kost, J. (2008). Modified pectin-based carrier for gene delivery: Cellular barriers in gene delivery course. Journal of Controlled Release, 130(2), 183-191.

Munarin, F., Tanzi, M. C., \& Petrini, P. (2012). Advances in biomedical applications of pectin gels. International Journal of Biological Macromolecules, 51(4), 681-689.

Smistad, G., Bøyum, S., Alund, S. J., Samuelsen, A. B. C., \& Hiorth, M. (2012). The potential of pectin as a stabilizer for liposomal drug delivery systems. Carbohydrate Polymers, 90(3), 1337-1344.

Semiha, K., Omer, B., U \& Erdener, K. (2008). Swelling and dye sorption studies of acrylamide/2-acrylamido-2-methyl-1-propanesulfonic acid/bentonite highly swollen composite hydrogels. J. reactive \& functional Polymers, 68, 458-473.

White, G. W., Katona, T., \& Zodda, J. P. (1999). The use of high-performance size exclusion chromatography (HPSEC) as a molecular weight screening technique for polygalacturonic acid for use in pharmaceutical applications. Journal of Pharmaceutical and Biomedical Analysis, 20(6), 905e912. 
الملخص العربي

Radiation syntheses and characterization of Pectin/acrylamide and

Pectin/Diethylaminomethylmethacrylate (DEAMA) hydrogels as Drug delivery systems

التخليق الأثعاعي ودراسة الهيدوجيلات المحضرة من البكتين والكريلاميد والبكتين والداي ايثيل امينوميثيل ميثاكريلات لاستخدامها في التصاعد المحكم للأدوية

لقد حازت الهيدروجيلات المحضرة من البوليمرات الصناعية والطبيعية علي اهنمام كبير في الونة ألاخيرة.

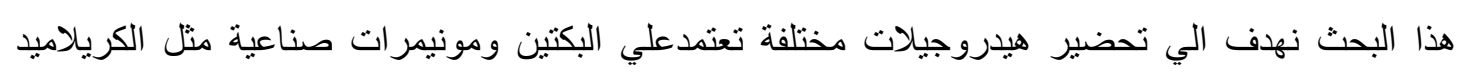
و الداي ايثيل أمينو ايثيل ميثأكريلات. فهذا البحث ايضا تم در اسة خاصية التو افق لهذه البوليمر ات مع البكتين وذللك

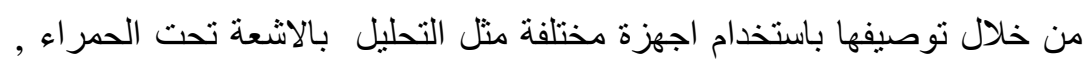
الثبات الحر اري و ايضا در اسة خاصية البلمرة الجيلاتينية والقدرة درجة بلمرة جيلاتينية للهيدروجيلات المحضرة من البكتين و الأكريلاميد حدثت بعد التعرض لجر عة اشعاعية 2

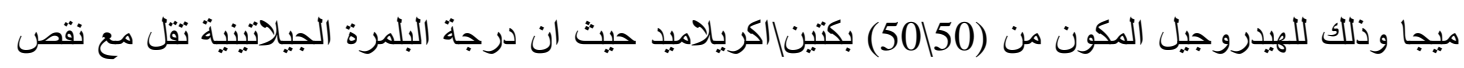
نسبة البكتين في الهيدروجيل وايضا تقل بزيادة الجر عة الأشعاعية اكثر من 2 ميجا. بينما بالنسبة الي الهيدروجيل

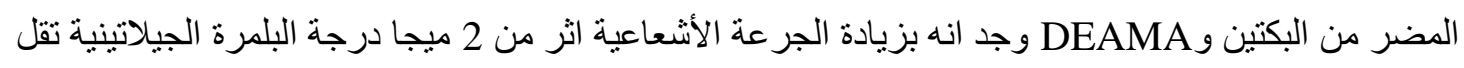
وذلك لزيادة درجة التشابك العرضي في الهيدروجيل. بدر اسة القدرة الأمتصاصية للماء للهيدروجيلات المحضرة وذلك تحت تأثير درجة الحرارة والأس الهيدروجيني للوسط لوحظ ان قدرة الامتصاص للهيدروجيلات المختلفة تتغير بتغير درجة الحرارة والاس الهيدروجيني, حيث ان قدرة الهيدروجيل المكون من البكتين و الأكريلاميد علي لئي

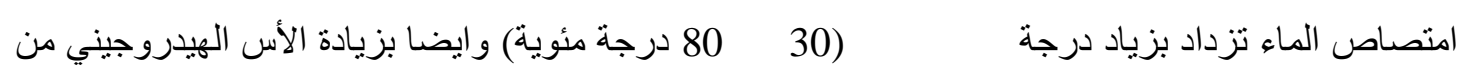

DEAMA 8 بزيادة درجة الحرارة وتقل بزيادة الأس الهيدروجيني في الوسط. كما لوحظايضا ان قدرة الهيدروجيل الم 
من البكتين و الأكريلاميد علي امتصاص الماء اعلي من الهيدروجيل المكون من البكتين و ال DEAMA. هذا الصدد قد تم تفعيل استخدام هذه الهيدروجيلات للبكتين في تحميل وتحرر الأدوية مثال علي ذلك دواء التتر اسيكلين هيدروكلور ايد وذللك عند اس هيدروجيني من 2 8 8 الماء مع تغير الزمن حيث اثبتت الدراسة

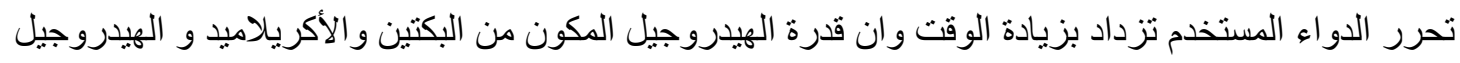
المكون من البكتين و ال DEAMA علي تحرر الدواء المستخدم قد حدث عند ألأس الهيدروجيني 8. ايضا من خلال هذه الدراسة لوحظ ايضا ان قدرة الهيدروجيل المكون من البكتين والأكريلاميداعلي من قدرة الهيدروجيل المكون من البكتين و ال DEAMA 